
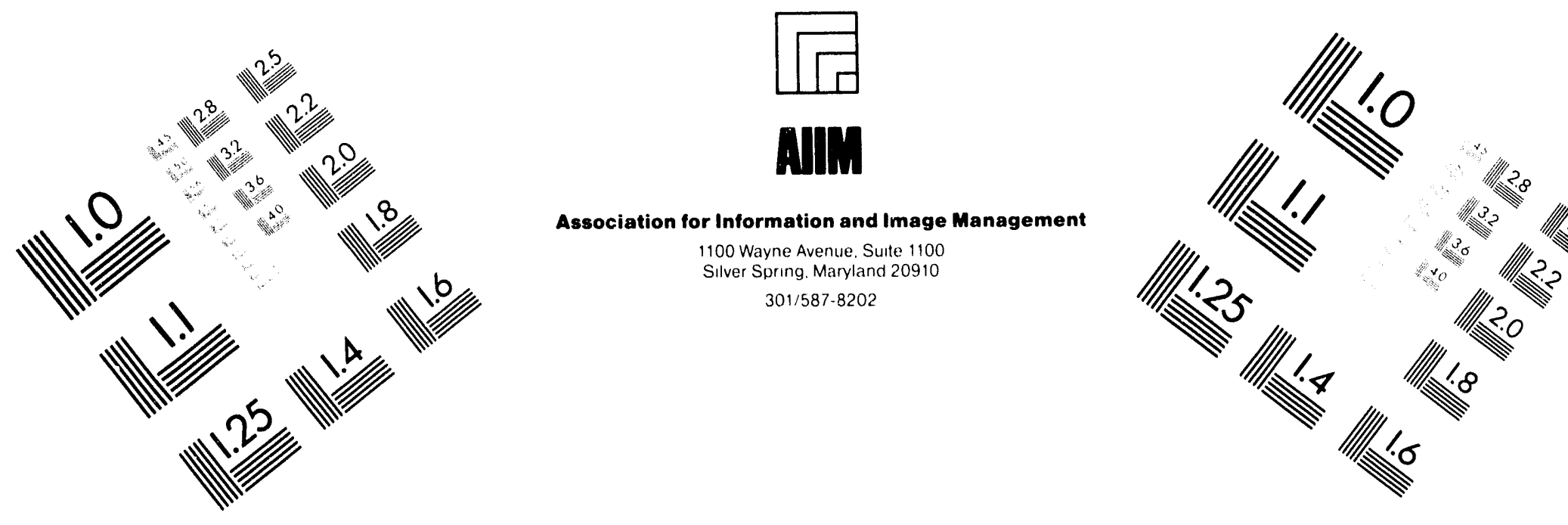

\title{
Centimeter
}

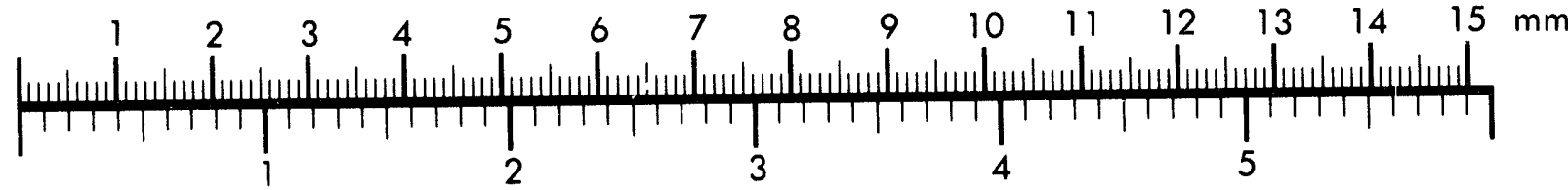

Inches
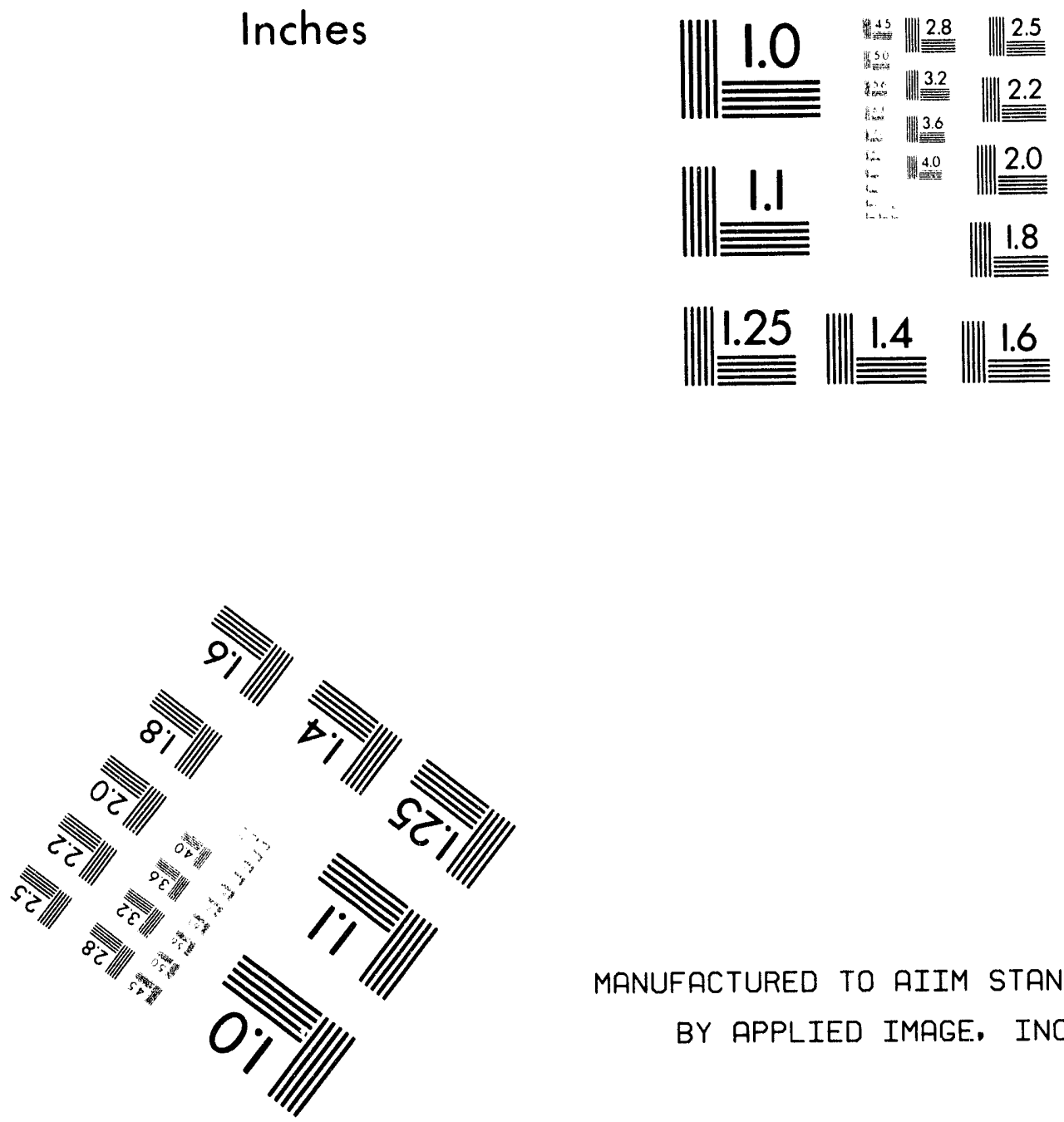

MANUFACTURED TO AIIM STANDARDS

BY APPLIED IMAGE. INC.

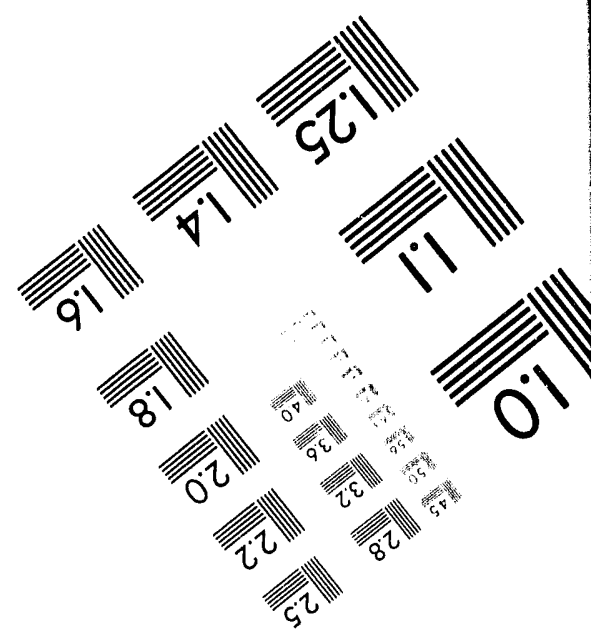



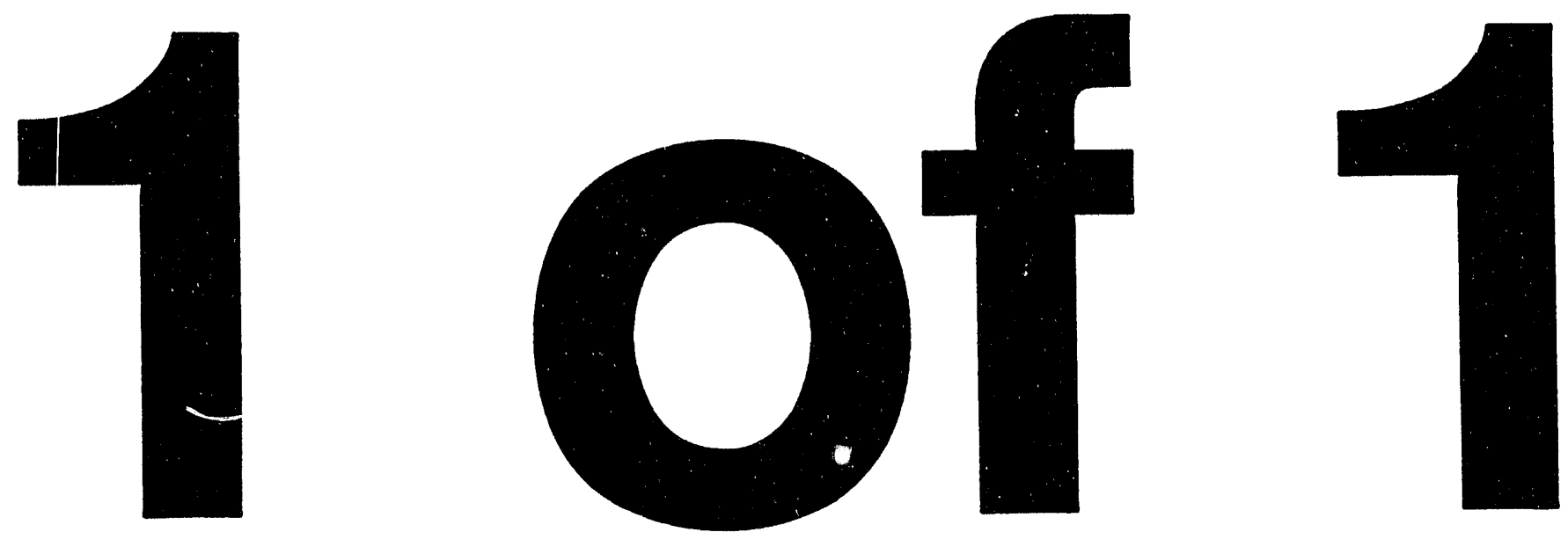


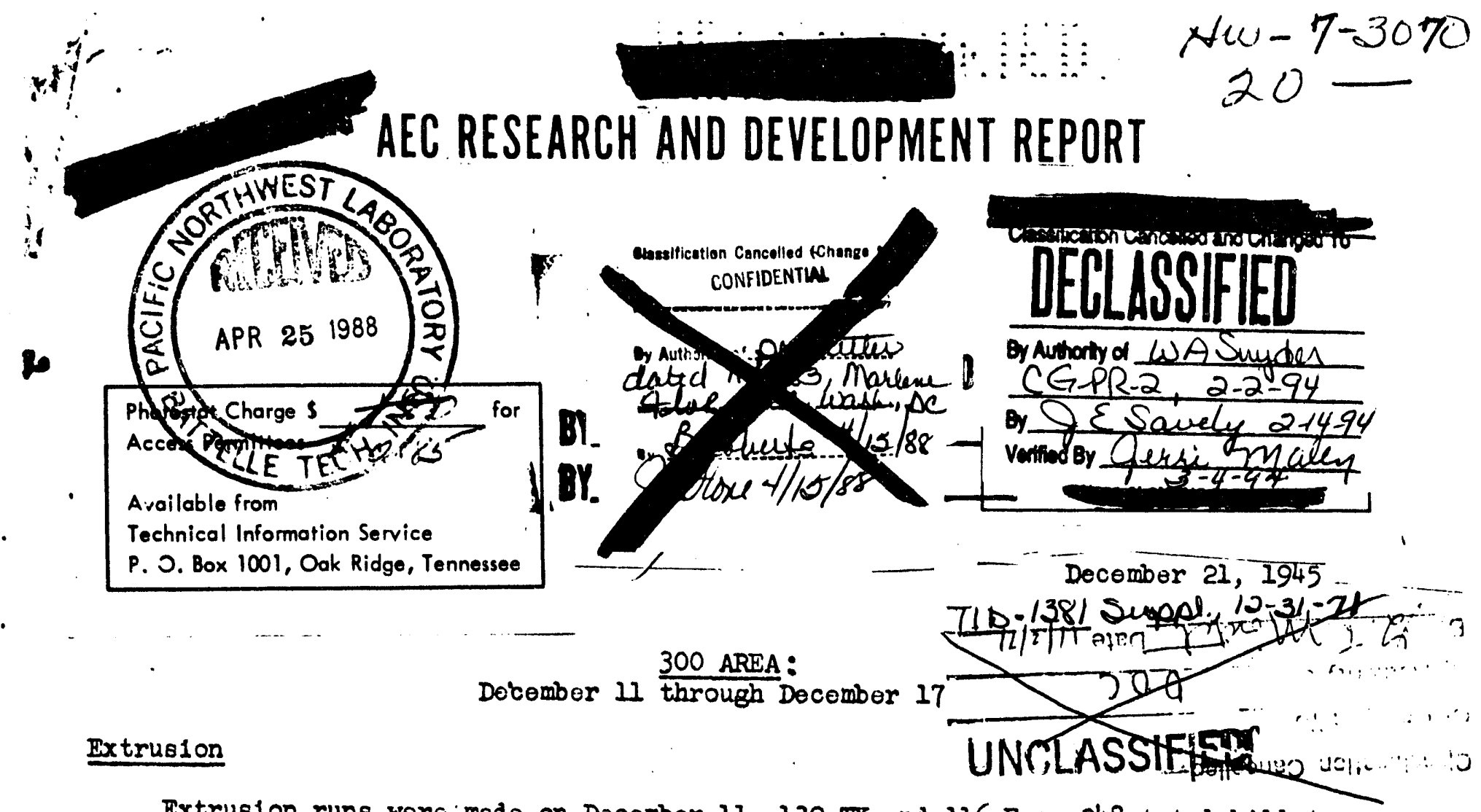

Extrusion runs wore made on Docember 11,132 IX and $116 \mathrm{E}$ or 248 total b11lets, and Locomber 12, $347 \mathrm{E}$ blllets.

Zone $8: x$ temporatures of the billet heating firmace were erratic, resulting in somo cold miterial and rod cropping. There wero bad gas pockots in Rods $\mathbf{E} 5123$ and 530: near the butt ends which are bolng given tochnical study. The caure is con-

* eldered to bo billet pipos or major porosity.

Changes wore tried on Decomber 13 to the stump shoar to trim fins from butts and sopnrste butts from dumm blocks. Tho new equipmont 1s considered promising; if ouccesoful, the recults will bo improved 11 fe and condition of dum blocks and contalners and also lese contamination of extrusion screp.

The ncw rod handing and quenching faclilties continued to work well. Some furthor attention is desirable in rod stralghtening on the run-out conveyor, to prevent alnked leading ends. This will be tried durlng the next oxtrusion.

Permanent tomporature indicating and recording instruments are st1ll required for container and rod temperatures. These are being investigated.

Dealen work is proceeding on chip cleaning and briquotting facilitieg. A roeting was held during the woek to discuss gonoral lay-outs and equipmont arrangemonts. Technical atudies are continuing on Production Test 314-34-M, covoring chip broeknrs and Improved chip quality from the machining operation.

The olugs machlned from roduced diameter rods on Production Test 314-33-M are I going through canning, with about average resulte so far. Canning of these will continuo urit1l abcit January 5 to 10.

A production test has boen arrangod on BT billets from the October and November : ohlpments; oomo of this materlal 1s ocheduled for extrusion th1s week.
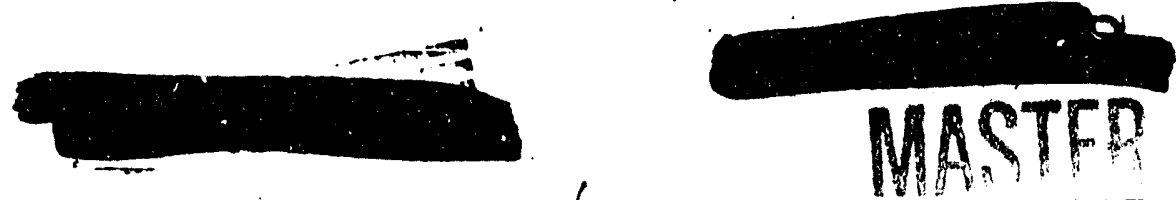


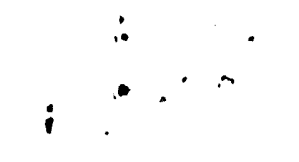

Canning

\section{Underwater Lathe}

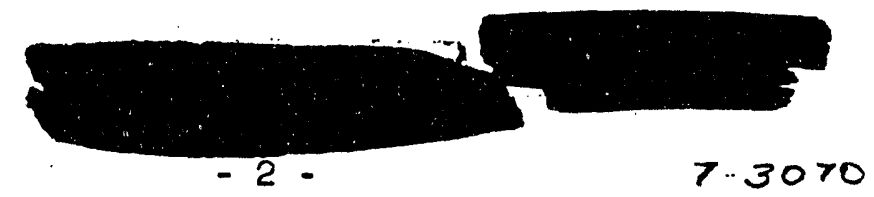

During the past 2 weeks work has beon progreseing on the design and canstruction of a emall lathe to be used under water in 100-B Area for the purpose of eectioning and examining canned ploces which have assumed irregular dimensions durlng exposure in the pile. This work has now been completed and the lathe hes boen trangferred to the 100-B Area. The work of actually sectloning the pleces in question will begin is $800 m$ as the current dischargo has been completed and the visibitily of plt vater 1o adequato.

\section{Production Tost 313-73 M-Small Dlameter Slugs (M Z)}

Tho summary of the comparison of approximately 15,000 pleces of MZ material w1 th approximately 20,000 pieces of A matericl sanned during October indicates that wh th respect to frost-test rejects, the $M Z$ plecos woro 0 . \% worse then A plecer; but that, with respect to wrinkled and non-seats the MZ pleces wero about 5\% bettor than A pleces. The avercge dih in the Tost Pile for $M Z$ materlal was $=0.224$ as compared to -0.144 for rogular $z$ material. Several lota of $M Z$ material had a dih of less than -0.290 , which is consldered the lowest acceptablo 11mit for $\mathrm{Z}$ materlel. An invostigation of the callses for thlo lower reactivity has shown evidence that the actual uranium content of the canned $M Z$ pleces is lese than that of the regular $z$ pleces, though the avorage uncannod wolghts for both are almost 1dentical. Furthermore, the 1080 of welght durling canning for regular $A$ materiel and for $M Z$ is very

- nearly the oame, while 1s the case of regular Z materlal, and of some A materlal that had been ground rather than turned to $\mathrm{Z}$ dimensions of 1.353+0.001-0.002 inches (designated as GZ) the welght 108s during canning was approximately half as much as for plecer having the turned surface. It thus appears that the rough ourface left by turning 19 conducive to more rapid solution of the base metal in the bathe than Is the smooth surface obtalned by grinding or through the canning and recovery proceseres.

In viow of the Improved yleld and low $108 \mathrm{~g}$ of reactivity (about 55 in loss $1 f$ the entire pile were loaded with $K$ eluge 1netead of A slugs) it bas been decided to adopt $\mathbb{R}$ eluge ae etendard for normal production.

\section{Magnosium Chloride Flux}

Earlier studiee directed at the development of a flux sultable for use in Tin Recovery indicated that the composition $44 \% \mathrm{KCL}, 56 \% \mathrm{Mg} \mathrm{Cl}_{2}$ (Tech. grade) would be satisfactory for tho purpose. However, it was found that, in uee, a flux of this composition gave off copious fumes of HCL during the initial stages of melting. It was believed that this fuming was caused by the eliminetion of water of hydration

$\because$ and molsture which had been absorbed by the deliquencent salt, elnce the fuming was

- greatly reduced after the flux had become completely fused. Attempto to dehydrate

2. the $\mathrm{MgCl}_{2}$ in avallablo equipment were unsuccessful. Laboratory tests were carried out and avallablo literature was consulted, from whlch the following concluaions were drawn:

a. Anhydrous $\mathrm{MgCl}_{2}$ cannot be prepered from the hydrate.

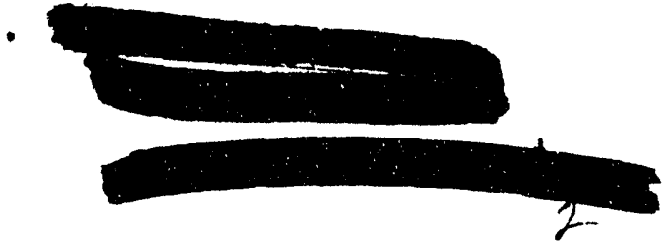



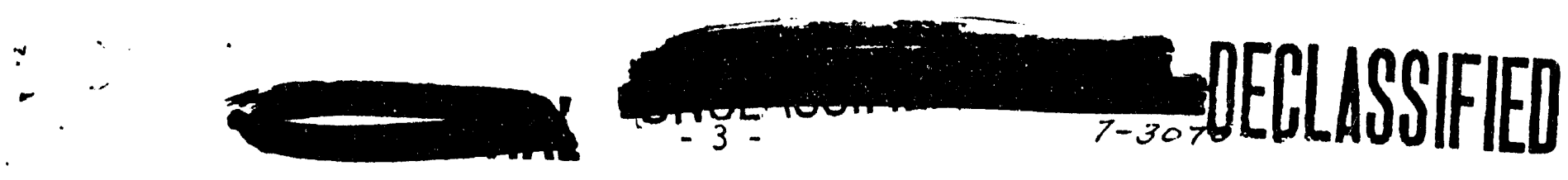

b. Fifty per cent of water present is olimnated by heating the oalt, as received, at $1700^{\circ} \mathrm{C}$ for 48 hours. Th1s is accompanied by tho evolution of atrong BCL fumos, and if carrled out in a drying oven, the latter mast bo constructod of acid-resiatant material, and must bo adequately rontod.

c. If drying is effected by rapid heating, the ailt cakes mast be ground bofore comounding a flux. Slower heatirig by conrection of air prevents caking.

d. Contamination of grinding equipment with $\mathrm{KgCl}_{2}$ has no apparent detrimental effect upon the branze flux subsoquentily put through the grinder. If $\mathrm{MgCl} / \mathrm{is}$ ground in this machine, the latter should be purged with somo other non-hygroscopic ealt to prevent absorption of molsture from the atmosphere resulting in corrosion of the equipment.

- Flux compounded from magnestum chlorlde as recelved compared with some made from the salt arled 48 hours at $170^{\circ} \mathrm{C}$ in the following respects: Fumoe from "dried" and "undrled" are comparable below 300 oc; abovo $300{ }^{\circ} \mathrm{C}$ the "undriod" evolves a considerably greater quantity of fumes, and continues to do 80 above $500^{\circ} \mathrm{C}$, whlle fumes from the "drled" practically cease above th1s temperature.

In view of the above consideratione, it appears that the best method of treating this material would be to compound the flux from the salt as 1s, and to dispose of the fumes by meane of \& fume hood placed above the furriace.

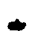

\section{Al-Si D1p Bath Composition Changes}

Analyols of twelve of the comtemplated twenty serles of samples to be taken during the current atudy of dip bath composition changes during use has been completed. Each serles consiete of 4 samples taken during the shift; one 1mmodiately aftor bath preparation in the morning, one just before and one just aftor motal addition at noon, and one at the cloee of the shift.

Resulte to date are in detall somewhat inconelstent and confuging, particularly in that expected changes due to metal additions are not reflected except in tho

- over-all picture presented by the data. The main polnte brought out thue far by the etudy appear, never the less, to bo quite definite; S1 loss during olght hours of bath use 1s considerably higher than expected, the dip bath consistently runs below specifled S1 content near the close of the shift when standardized Al-S1 is added at noon to bring up bath level, and it appears at least possible to hold bath comositions within spocifications oimply by using as-rcceived Al-si ingot (molten) to butt up at noon.

The following table shows data obtained to date:

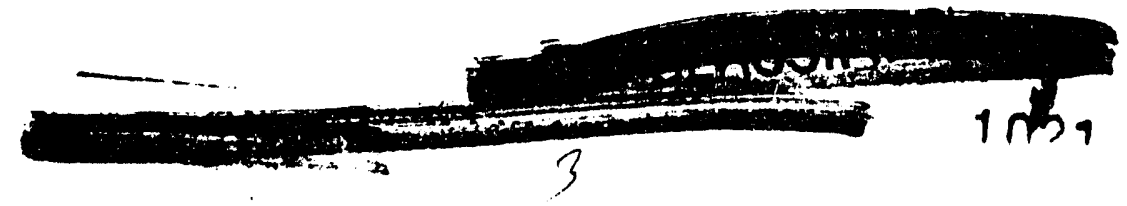




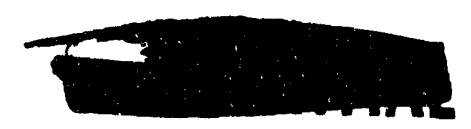

Serles No. Reported and Date Analyais \& T1me of Semple (\% s1)
Sample No., TIme, Etc.

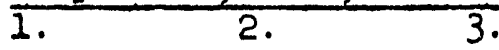
Approx. Just Be- After 8:00 A.M. (\% S1)
Ition at Noon (\% S1)

\subsection{0}

$\begin{array}{lll}\text { 1. } & 11-26-45 & \ldots . . \\ \text { 2. } & 11-27-45 & \ldots . . \\ \text { 3. } & 11-29-45 & 11.4 \\ \text { 4. } & 11-30-45 & 11.34 \\ \text { 5. } & 12-1-45 & 11.47 \\ \text { 6. } & 12-3-45 & 11.4 \\ \text { 7. } & 12-4-45 & 11.56\end{array}$

\begin{tabular}{ll} 
& 11.37 \\
A.M. & 11.42 \\
\hline$(8: 30)$ & 11.36 \\
$(8: 15)$ & 11.35 \\
$(8: 30)$ & 11.43 \\
$(9: 15)$ & 11.40 \\
$(9: 00)$ & 11.32
\end{tabular}

-...-

… $\quad 11.08$

11.20

- -

10.98

-...

11.20

10.9-

$11.04 \quad 10.97$

$\begin{array}{lll}\ldots . . & 11.29 & 11.08\end{array}$

... $\quad \ldots . .910 .94$

$\begin{array}{lll}\ldots . . & 11.09 \quad 11.02\end{array}$

All the above were taken with atandardized metal additione made at noon; the following with a receired ingot.

$\begin{array}{rlllllll}\text { 8. } & 12-5-45 & 11.4- & (9: 00) & 11.39 & 11.31 & 11.22 & 11.13 \\ 9 . & 12-6-45 & 11.38 & (8: 45) & 11.30 & 11.26 & 11.24 & 11.26 \\ 10 . & 12-7-45 & 11.29 & (11: 45) & 11.32 & 11.20 & 11.09 & 11.04 \\ 11 . & 12-8-45 & 11.30 & (9: 30) & 11.13 & -1 .- & 11.13 & 10.95 \\ 12 . & 12-10-45 & 11.18 & (\# 2) & 11.30 & 11.10 & 11.20 & 11.13\end{array}$

Examination of the data showe that with standardized metal additiona, all - 4:00 P.M., analyees were well below the specified minlmum, (11.2\% S1), whereas only two of flve taken while high $S 1$ additions were belng made were distinctly out of specifications. Th1s is in epite of the fect that the starting Si cantents of the latter were generally lower than those of the former. The fact that only one (Serlee No. 12, Sample No. 2, vo No. 3) showe the expected $0.1 \%$ approximato rige in Si content after tho addition of about 30 pounds of high $S 1$ motal cannot be explained. The averaged data followa:

\begin{tabular}{|c|c|c|}
\hline & $\begin{array}{l}\text { Standardized } \\
\text { Motal Added } \\
\end{array}$ & $\begin{array}{c}\text { High S1 } \\
\text { Metal Adde }\end{array}$ \\
\hline $\begin{array}{l}\text { S1 Content of otarting bath, ave } \\
\text { S1 Content after } 8 \text { hours use, ave. } \\
\text { S1 Lose during } 8 \text { hours use, ave. } \\
\text { Maximim lose } \\
\text { Minimum lose }\end{array}$ & $\begin{array}{r}11.38 \\
11.0 \\
0.38 \\
0.46 \\
0.30\end{array}$ & $\begin{array}{r}11.29 \\
11.1- \\
0.20 \\
0.28 \\
0.04\end{array}$ \\
\hline
\end{tabular}

It may be noted that the control analyses in elght caseo out of ten showed

- agreement with corresponding analyses made in the laboratory during this otudy. The other two, however, were at grose varlance. The cause of euch variation is the subject of a eeperate etudy now being made.

An Incidental obeervation was that on December 7 and Decembor 8, (Series No. 10 and 11) a large number of wrinkled cans was produced. Of the last five serles
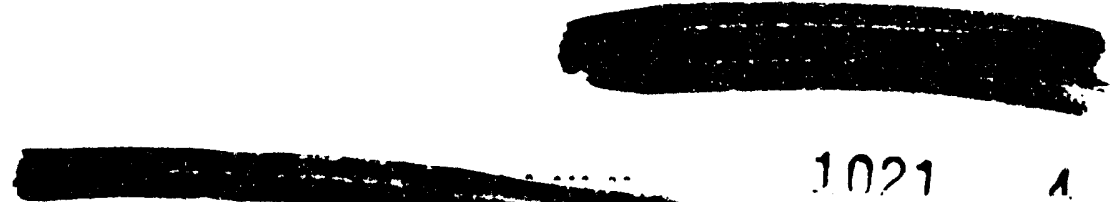


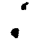

$-1$

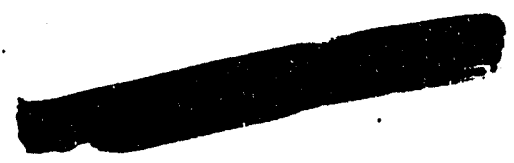

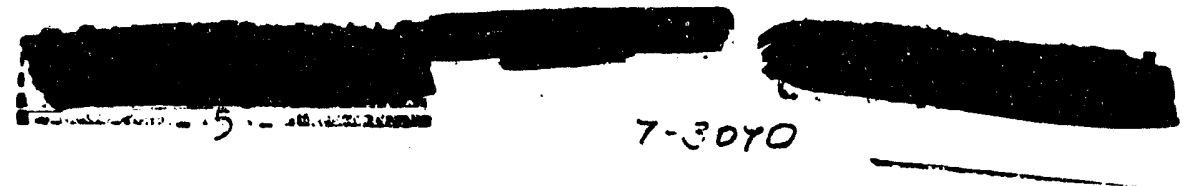

these two were the only ones bolow speclfications after the noon addition of metal, and had the lowest Si content at 4:00 P.M. This 18 distinctly contrary to previous notions regarding wrinklod cans.

It has been proposed that a 50-pound addition (involving oome balling if necessary) of high S1 metal be made at noon 1nstead of the present thirty. This should hold the bath within specifications if the atarting composition is correct.

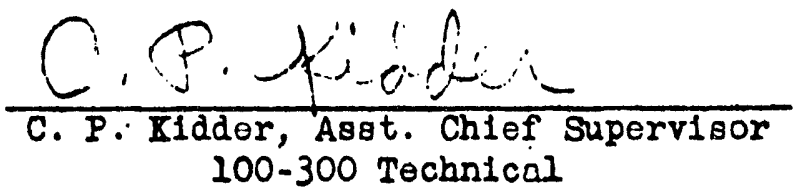

DELLSSSFFED 

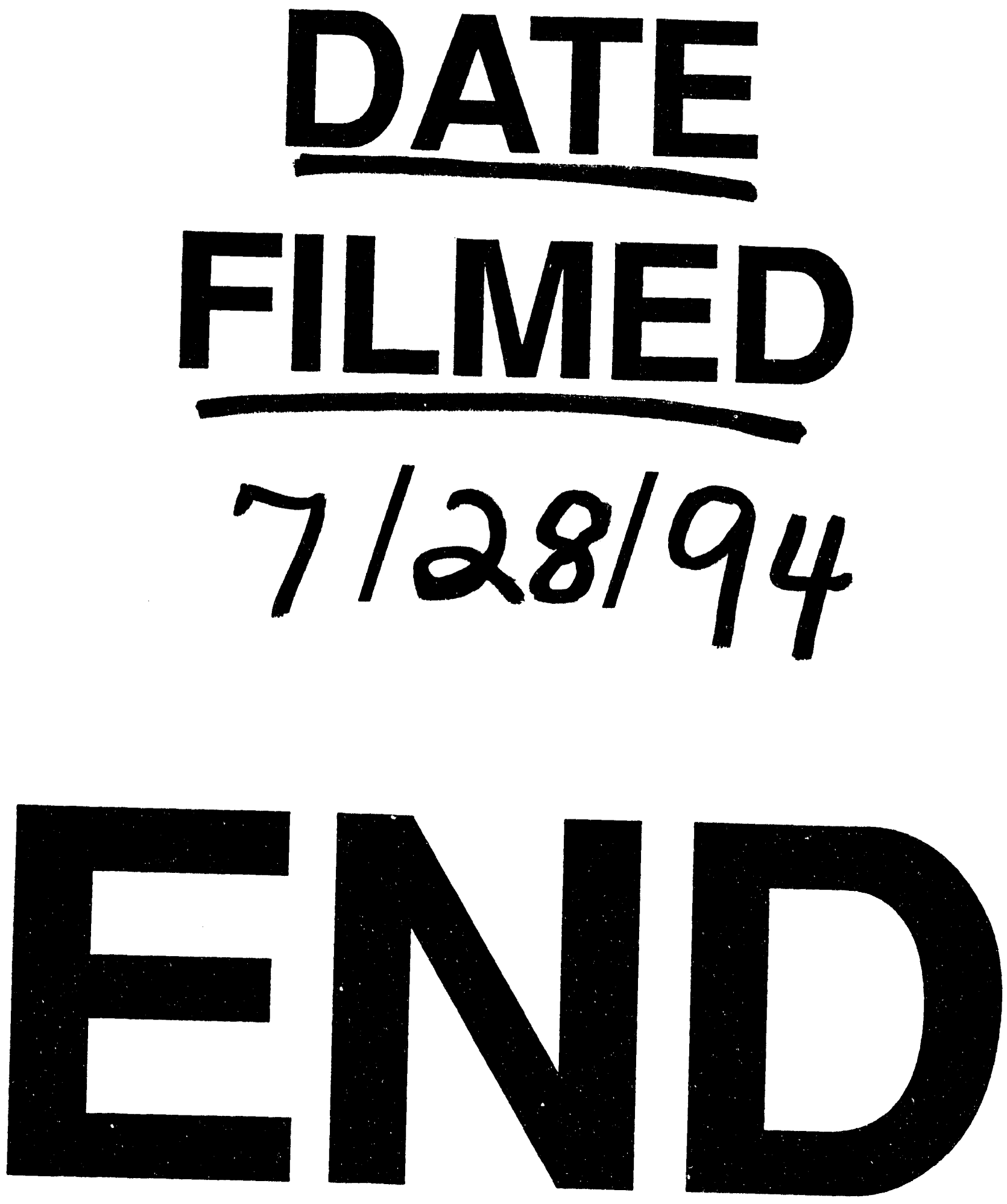
